\title{
Effectiveness and Injury Risk during Timber Forwarding with a Quad Bike in Early Thinning
}

\author{
Arkadiusz Stańczykiewicz (D), Dariusz Kulak, Krzysztof Leszczyński *D, Grzegorz Szewczyk and Paweł Kozicki \\ Department of Forest Utilization, Engineering and Technology, Faculty of Forestry, University of Agriculture in \\ Krakow, Al. Mickiewicza 21, 31-120 Kraków, Poland; arkadiusz.stanczykiewicz@urk.edu.pl (A.S.); \\ dariusz.kulak@urk.edu.pl (D.K.); grzegorz.szewczyk@urk.edu.pl (G.S.); pawel.kozicki@student.urk.edu.pl (P.K.) \\ * Correspondence: krzysztof.leszczynski@urk.edu.pl; Tel.: +48-12-6625-087
}

Citation: Stańczykiewicz, A.; Kulak, D.; Leszczyński, K.; Szewczyk, G.; Kozicki, P. Effectiveness and Injury Risk during Timber Forwarding with a Quad Bike in Early Thinning. Forests 2021, 12, 1626. https:// doi.org/10.3390/f12121626

Academic Editor: Gianni Picchi

Received: 22 October 2021

Accepted: 20 November 2021

Published: 24 November 2021

Publisher's Note: MDPI stays neutral with regard to jurisdictional claims in published maps and institutional affiliations.

Copyright: (C) 2021 by the authors. Licensee MDPI, Basel, Switzerland. This article is an open access article distributed under the terms and conditions of the Creative Commons Attribution (CC BY) license (https:// creativecommons.org/licenses/by/ $4.0 /)$.
Abstract: Within the majority of forest areas where timber is harvested for industrial and energy purposes, working technologies using highly efficient multi-operational machinery and equipment are employed. The situation is different in fragmented, privately owned forests. In such forests, timber harvesting is mainly based on motor-manual technologies with a high proportion of manual labor, both at the stage of felling and timber processing and at the stage of its transport. The study aimed to characterize the work time structure of the ATV unit driver and his helper, to determine the productivity of this team, and to estimate the risk of injury during manual loading and unloading. Based on the data collected during the field research, the theoretical work time structure, work productivity and costs, and injury risk were estimated as a result of using a professional small trailer equipped with a hydraulic crane for timber forwarding, designed for aggregation with the ATV. The average, calculated productivity of timber forwarding (over an average distance of about $500 \mathrm{~m}$ ) with manual loading and unloading was almost twice as low as the estimated average productivity of forwarding with mechanical loading and unloading using a hydraulic crane. The total unit costs (including labor costs) of forwarding with manual loading and unloading were almost threefold higher than those of forwarding using a trailer with a hydraulic crane. The use of small forest trailers equipped with a hydraulic crane not only ensures higher productivity and cost effectiveness but also allows reducing (even by several percent) the inconvenience of manual timber handling and the risk of strain of the musculoskeletal system.

Keywords: all-terrain vehicle-ATV; work time structure; productivity; extraction costs; musculoskeletal strain

\section{Introduction}

The forest area in Poland covers over 9.4 million ha. In contrast to the forests of Western Europe [1] and Scandinavia [2], nonindustrial private forests do not constitute a dominant share [3]. These forests cover more than 1.75 million ha or $19 \%$ of the country's area [4]. In the last 5 years, coarse timber harvesting in privately owned Polish forests increased from 1.24 million to 1.53 million $\mathrm{m}^{3}$, which represents $3.8 \%$ of total harvesting in forests in the country. About $21.8 \%$ and $18.5 \%$ of harvested timber is medium-sized and used for industrial purposes and as fuelwood, respectively. Meanwhile, in the US, about $50 \%$ of the timber is harvested in nonindustrial private forests, which cover 59\% of all forest land [5]. In Polish state forests, about 35\% of timber is harvested by applying high-productivity machine technologies using harvesters, forwarders, and even harwarders [6-10], while timber in private Polish forests is harvested by applying motor-manual technologies using chainsaws for felling, delimbing, and cross-cutting, and mostly farm tractors equipped with many different devices for timber transportation [11,12]. A similar technical level is observed in logging in private forests in Romania. In Latvia's private forests, on the other hand, part of the timber is harvested using machine technologies [13]. 
Machines and devices developed through small-scale mechanization, including processors aggregated with farm tractors [14,15], small tractors [16,17], or light winches driven by chainsaw engines $[18,19]$, are used within state forests very rarely. Since the beginning of the present century, reports on the widespread use of miniscale machines and equipment, such as skidders, forwarders [20-23], and ATVs [24], in logging and forwarding have been published. Studies indicate that, as early as the end of the last century, several thousands of these vehicles were sold to private forestry operations in the United Kingdom annually [25]. These vehicles are used in many parts of the world primarily for transportation of equipment and materials used in forest restoration, logging, and fire protection works. The advantages of these vehicles, which are particularly useful for forestry work, include four-wheel drive to improve traction and low-pressure tyres to reduce ground pressure. Their disadvantages include, in particular, poor low-speed power delivery, limited rated pulling power, and the absence of PTO (power take-off) or three-point linkage [26]. However, between 1987 and 2002, the sales of ATVs in Sweden steadily increased from about 500 to over 3200 units and that of ATV-adapted trailers from about 400 to over 1700 units [2]. In Colorado, approximately 3\% of private contractors use ATVs equipped primarily with skidding arches for timber harvesting [27]. In order to improve the usability of ATVs in forest areas, it is recommended to adapt them by installing rear wheel chains, a counterweight at the front, a protective plate under the engine, guards for the driver's feet, and a cable winch and filling the tires with fluid. In agriculture, the quad bikes are mainly used for livestock operations, transportation of goods and personnel, and crop operations $[28,29]$.

During timber transport, ATVs are utilized for dragging or skidding [20], forwarding, or suspended skidding with the use of, for example, skidding arches [30,31].

Minivehicles are used in many forested areas in several regions (e.g., Europe or North America), as evidenced by published guides on their proper use in logging and timber transport operations [31,32]. An increasing number of devices are available on the market (mostly manufactured in Scandinavian countries), which can be aggregated with minivehicles [33-36]. In addition, current research focuses on formulating solutions to improve the safety of ATV operators [37-39] and on determining the impact of various mechanisms and factors, such as approach angles, trailer towing, adding weight above or below the center of gravity (e.g., by the use of ROPS (rollover protective structures), heavier operators, and counterweights), track width, tire pressure, and suspension stiffness, on the stability of ATVs aggregated with small forest trailers [40]. The effects of tourist ATV utilization on forest soils and grasslands [41] and forest watercourses [42] have also been studied and analyzed. The last research and analysis of the effectiveness of forwarding with ATVs was conducted almost two decades ago [43-45]. Therefore, the present research is an attempt to update and expand the knowledge in this area, especially as ATVs are becoming increasingly popular in small-scale forestry, and the heavy loads (on average, over $500 \mathrm{~kg}$ [40]) on a quad or trailer associated with professional use result in an increased risk of accidents.

This study was performed to determine the work time structure, productivity, and costs of timber forwarding carried out with an ATV unit, which was loaded and unloaded manually. In the further part of this article, this mode of operation is referred to as "manual work/manual loading and unloading". In addition, the study estimated the risk of musculoskeletal injuries involved with manual lifting of timber during loading and unloading. The data collected from field research were used to estimate work time structure and the productivity, injury risk, and costs of using a professional small trailer, which was designed for aggregation with an ATV and equipped with a hydraulic crane. In the further part of the article, this procedure is referred to as "mechanical work/mechanical loading and unloading". The studies and analyses carried out were intended to indicate which work activities would change and to what extent if manual loading and unloading were to be replaced by mechanical loading and unloading using a hydraulic crane. Moreover, it was hypothesized that net productivity is affected by the number of bolts loaded during 
one forwarding cycle in the case of manual loading and the number of grapple loads in the case of mechanical loading, as well as by forwarding distance $(\mathrm{m})$ and load volume $\left(\mathrm{m}^{3}\right)$. From an ergonomic point of view, the studies and analyses carried out were intended to indicate the differences between the risk of injury estimated for manual work and for work using a hydraulic crane. The economic analyses were to show the differences between the calculated costs of performing manual work in forwarding and the estimated costs of performing work with loading and unloading by means of a hydraulic crane.

\section{Materials and Methods}

This study was carried out in the Olkusz Forest District, which is located in Malopolskie Province in the southern part of Poland, within the boundaries of the Regional Directorate of State Forests in Katowice (Figure 1). The Forest District manages over 16,800 ha of forests owned by states. In addition, through a commission from a Local Government Unit (Starostwo in Olkusz) and based on a simplified Forest Management Plan, it supervises the forests belonging to private owners, having a total area of 2128 ha. In 2017-2019, a total of $7310 \mathrm{~m}^{3}$ of timber was harvested in the forests supervised by the Forest District, including $4827 \mathrm{~m}^{3}(66 \%)$ of sawn timber and $2483 \mathrm{~m}^{3}(34 \%)$ of industrial timber. Timber harvesting in the private forests is mostly carried out by the owners' own forces; but, in some cases, the owners use the services of foreign companies that also serve the forests managed by the Forest District.

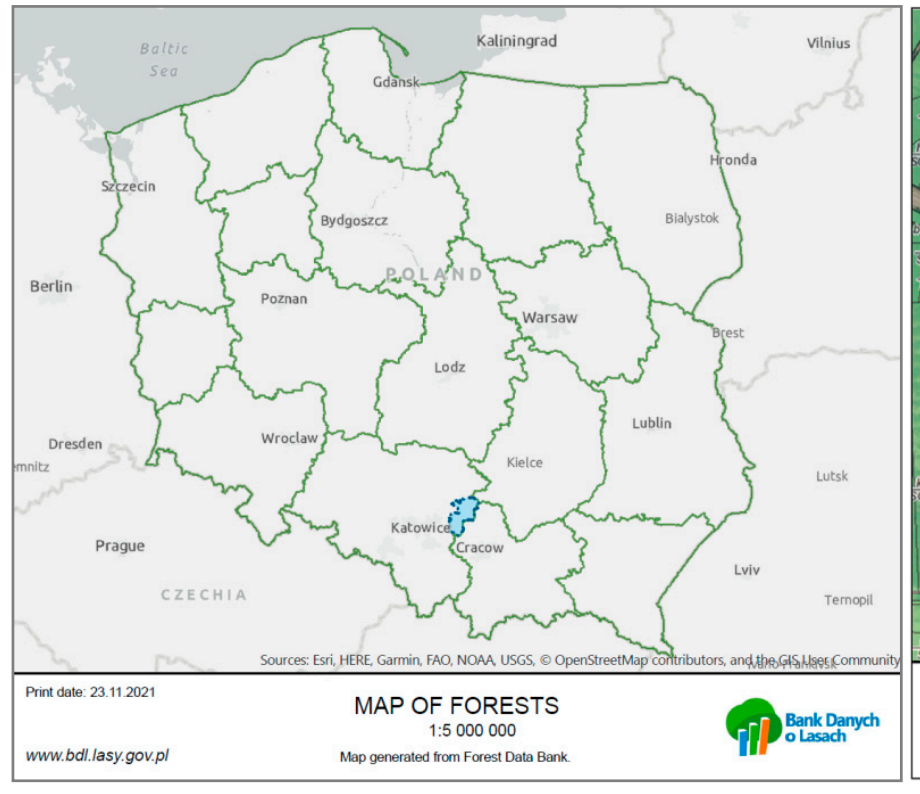

(a)

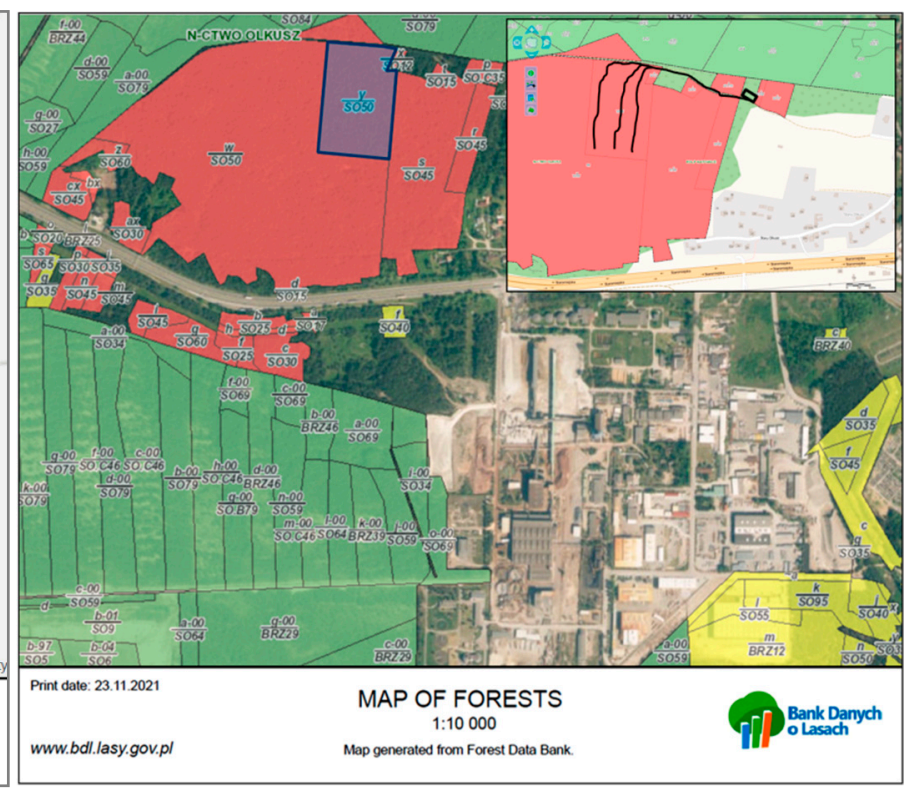

(b)

Figure 1. Location of the Olkusz Forest District in Poland (a) on the background of the Regional Directorate of State Forests in Katowice and the stands (b) where the study was carried out (blue rectangle) with a simplified scheme of the main operating routes, and timber landing (rectangle). On the right, State Forests are marked in light green, private forests in light red, and forests of the town of Olkusz in yellow, source: [46].

The study was conducted in a privately owned pine stand typical for this region of Poland, in which late thinning was planned. The detailed characteristics of the pine stand are presented in Table 1. 
Table 1. Characteristics of the stand.

\begin{tabular}{|c|c|c|c|c|c|c|c|}
\hline Location & $\begin{array}{c}\text { Area } \\
\text { (ha) }\end{array}$ & $\begin{array}{c}\text { Stand } \\
\text { Composition }\end{array}$ & $\begin{array}{c}\text { Age } \\
\text { (Years) }\end{array}$ & $\begin{array}{l}\text { DBH } \\
(\mathrm{cm})\end{array}$ & $\begin{array}{l}\text { Height } \\
\text { (m) }\end{array}$ & $\begin{array}{c}\text { Growing Stock } \\
\left(\mathrm{m}^{3} \times \mathrm{ha}^{-1}\right)\end{array}$ & $\begin{array}{c}\text { Thinning } \\
\left.\text { Intensity (m }{ }^{3}[\%]\right)\end{array}$ \\
\hline $\begin{array}{l}19.527 \mathrm{~N}, \\
50.291 \mathrm{E}\end{array}$ & 3.68 & $\begin{array}{l}80 \% \text { Scots pine } \\
20 \% \text { Black pine }\end{array}$ & 53 & 24 & 20 & 240 & 88 [10] \\
\hline
\end{tabular}

Approximately $10 \%$ of the timber volume from the entire compartment area was planned to be harvested for this study (Table 1). In accordance with the Polish Forest Management Rules, trees to be felled were designated by the forest district employee who was responsible for supervising the harvesting process in private forests. The study was conducted in February 2019, during winter with a fragmentary snow cover of up to $10-\mathrm{cm}$ thickness. Timber harvesting was carried out by applying motor-manual technology within the CTL (Cut-To-Length) method [47,48]. In this method, trees are felled, delimbed, and bucked into timber assortments directly in the stump area. The assortments are then extracted to the roadside and unloaded into separate piles on landings. In the present study, felling and timber processing were performed using a chainsaw and forwarding was performed using an ATV aggregated with a lightweight trailer. This trailer was equipped with a bogie chassis without additional wheel drive (Figure 2). The detailed technical characteristics of the ATV unit with trailer used in this study are presented in Table 2, along with the technical characteristics of a trailer with a hydraulic crane. This trailer was offered by one of the Scandinavian manufacturers (model 21-SV36) and had the most similar parameters as the trailer used in the study. Figure 3 shows a small trailer with a hydraulic crane offered on the market by another Scandinavian manufacturer, which has very similar technical parameters to the model used in the analyses [36].

Table 2. Technical characteristics of a forwarding set without a crane and with a hydraulic crane.

\begin{tabular}{|c|c|c|c|c|}
\hline Type & Unit & $\begin{array}{c}\text { ATV CF MOTO } \\
\text { AllroadCF500 }\end{array}$ & $\begin{array}{l}\text { Trailer without a } \\
\text { Hydraulic Crane }\end{array}$ & $\begin{array}{c}\text { Trailer with a } \\
\text { Hydraulic Crane }\end{array}$ \\
\hline Engine capacity and power & $\begin{array}{l}\mathrm{cm}^{3} \\
(\mathrm{~kW})\end{array}$ & $493(24)$ & - & - \\
\hline $\begin{array}{c}\text { Engine power of the hydraulic } \\
\text { aggregate }\end{array}$ & $\mathrm{kW}$ & - & - & 4.8 \\
\hline Hydraulic system pressure & bar & - & - & 150 \\
\hline Fuel tank capacity & $\mathrm{dm}^{3}$ & 20 & - & $3.1^{*}$ \\
\hline Maximum torque & $\mathrm{Nm} / \mathrm{rpm}$ & $36 / 5500$ & - & - \\
\hline Weight & $\mathrm{kg}$ & 357 & 380 & 510 \\
\hline Range of the crane & $\mathrm{m}$ & - & - & 3.6 \\
\hline Load capacity at $3.0-\mathrm{m}$ range & $\mathrm{kg}$ & - & - & 175 \\
\hline Maximum grapple working area & $\mathrm{m}^{2}$ & - & - & 0.08 \\
\hline Payload & $\mathrm{kg} / \mathrm{m}^{3}$ & 210 & $1800 / 1.7(2.5 \mathrm{~m}) * *$ & $2000 / 2.0(3.0 \mathrm{~m})$ \\
\hline Dimensions (length/width) & $\mathrm{mm}$ & $2320 / 1170$ & $3450 * * * / 1350$ & $3000-3900 / 1350$ \\
\hline Cross-section of the load compartment & $\mathrm{m}^{2}$ & - & 0.68 & 0.68 \\
\hline Clearance & $\mathrm{mm}$ & 290 & 390 & 410 \\
\hline Tires & - & AT $5 \times 8(10)-12 * * * *$ & AT $23 \times 8-12$ & AT $23 \times 10-12$ \\
\hline
\end{tabular}

${ }^{*}$ Hydraulic aggregate; ${ }^{* *}$ maximum length of the timber to be forwarded $(\ldots)$; ${ }^{* * *}$ length with drawbar and hitch ball; ${ }^{* * * *}$ front (rear).

Timber was forwarded in the form of 2.5-m-long bolts over flat, low-diversity terrain to a stockpile which was $200 \mathrm{~m}$ from the cutting area boundary (Figure 1). The total forwarding distance ranged from 235 to $665 \mathrm{~m}$. The cutting area was not accessible by a network of operating trails. Timber from irregular piles, which were arranged after delimbing and cross-cutting, was loaded manually by two workers. Piles of several bolts to several dozen bolts were distributed over the entire cutting area (Figure 4). 


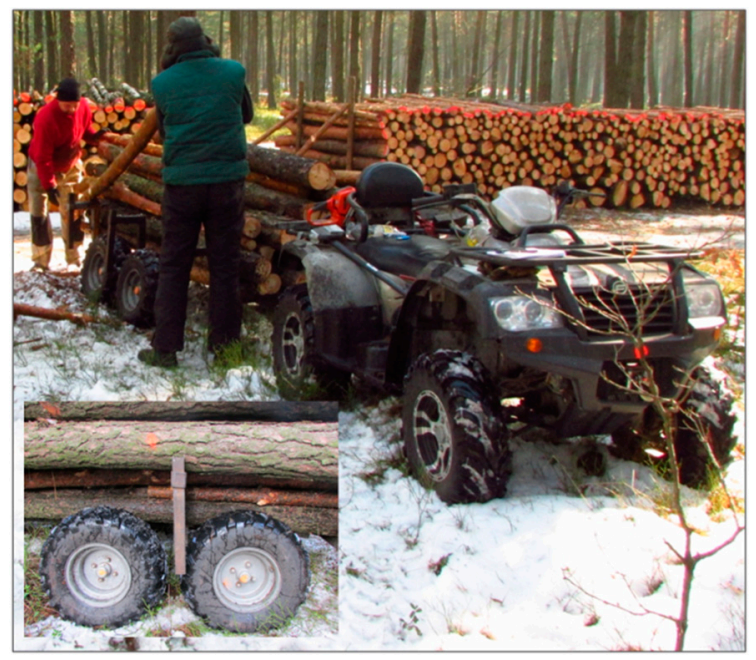

Figure 2. ATV and trailer during unloading on forest landing (photo: P. Kozicki).

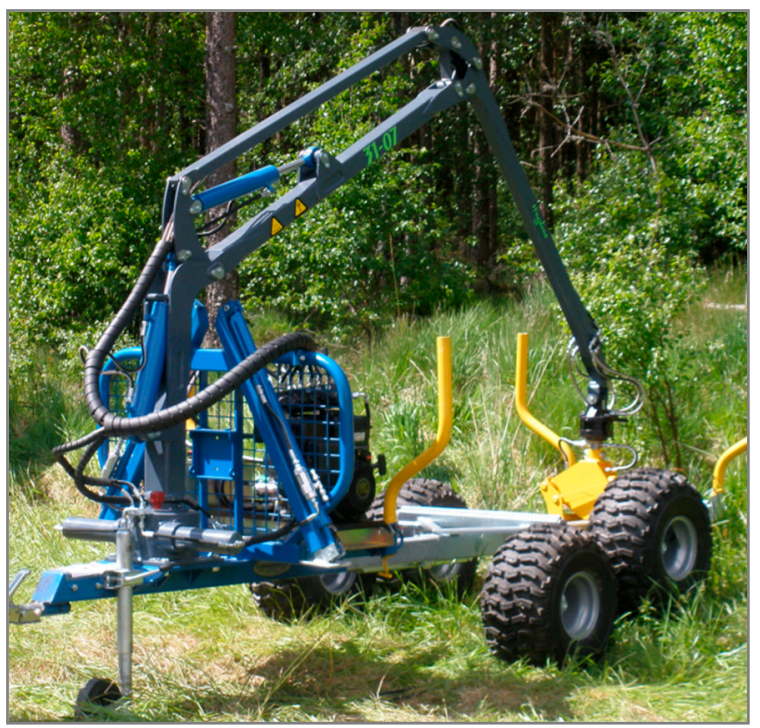

Figure 3. Trailer 31-07 with grapple loader (photo: A. Stańczykiewicz).

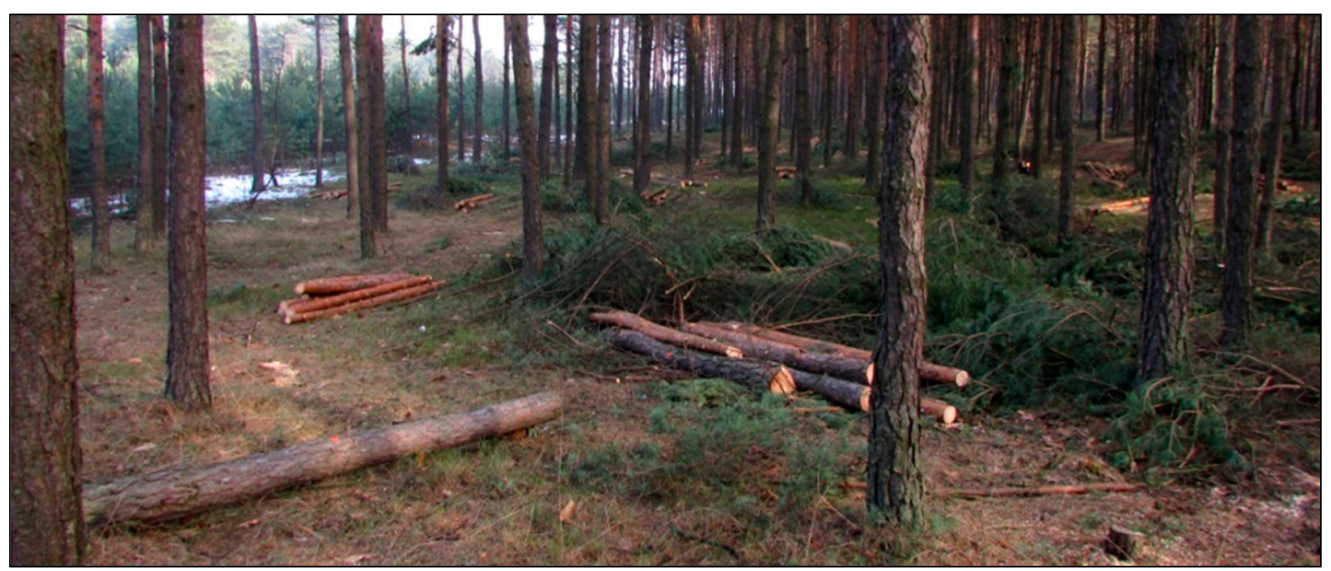

Figure 4. View of a section of the stand with irregularly arranged piles of timber (photo: P. Kozicki).

The forwarder unit operation was observed during six work shifts. Work time was measured using TIMING application installed in a PSION Workabout MX 2MB portable 
handheld microcomputer (PSION TEKLOGIX Inc., Mississauga, ON, Canada). The application allows recording the duration of all the observed activities with an accuracy of $1 \mathrm{~s}$. Prior to loading, the mid-diameter of each bolt was measured using a caliper, and the number of all piles stacked on the cutting area as well as the number of individual bolts in each pile was calculated. During loading, the number of total bolts transported within each course to the landing was recorded. The volume of each bolt was calculated based on the length and mid-diameter over the bark. The time structure analyses were carried out using a classification based on IUFRO guidelines [49,50]. During each working shift, measurements were started at the time of the beginning of the first ATV unit ride from the landing toward the cutting area and ended at the end of timber piling after the last course of the unit to the landing. All the activities observed during the individual work cycles of the working unit are described under the characteristics of working times.

Workplace time $(\mathrm{WP}=\mathrm{ME}+\mathrm{RP}+\mathrm{PW}+\mathrm{SW})$ included the following:

- $\quad$ non-work time (NT), which included:

$\checkmark \quad$ breaks for eating restorative meals, warming up by the fire, and drying soggy outer clothing and work gloves (mealtime, ME);

$\checkmark \quad$ rest periods before or after manual loading or unloading of timber and short breaks for physiological needs, telephone conversations, and smoking (rest and personal time, RP);

- $\quad$ work time $(\mathrm{WT})$, which included:

productive work time (PW), which included:

$\bigcirc \quad$ time of timber loading and unloading (including time of unfolding and folding the trailer's supports), time of timber forwarding (full load) to the landing (main work time, MW), and

$0 \quad$ time of unloading rides from the landing to the cutting area (rides without load), time of rides between the individual stages of timber loading (rides during loading), and time of placing timber pads and securing the piles against shifting to the sides (pile-place preparing) (complementary work time, CW),

$\checkmark \quad$ supportive work time (SW), which included:

- time to repair a failure related to the tightening of the trailer wheel, fixing bolts (repair time, RT),

time spent refueling (refuel time, RF), and

time taken for checking and servicing the basic components of the unit used for checking the pressure in the trailer wheels or lubrication state of the joints (maintenance time, MT).

The measured times of activities that fall within the scope of workplace time (WP) were used to calculate (in the case of manual work) and estimate (in the case of mechanical work) gross productivity, which is expressed as $\mathrm{m}^{3} \times \mathrm{SMH}^{-1}$. The measured times of activities that fall within the scope of productive work time (PW) were used for the calculation (in the case of manual work) and for the estimation (in the case of mechanical work) of net productivity, which is expressed as $\mathrm{m}^{3} \times \mathrm{PMH}^{-1}$.

The revised NIOSH lifting equation for repetitive multitasks of duration over $2 \mathrm{~h}[51,52]$ was used to assess the risk of musculoskeletal injuries resulting from manual handling work (lifting, carrying, lowering bolts of timber). This analysis assessed the manual handling tasks associated with loading and unloading, which were performed by a two-person team due to the volume of the individual bolts (significant weight, 2.5-m length). It was assumed that the workers were loaded uniformly and that specific risk indicators (Single-Task Recommended Weight Limit (STRWL), Frequency-Independent Recommended Weight Limit (FIRWL), Frequency-Independent Lifting Index (FILI), Composite Lifting Index (CLI)) characterize the load of a single worker. For assessing the risk of injury resulting from manual placement of timber stacking pads by the operator of an ATV unit equipped with a 
trailer and a hydraulic crane, it was assumed that the diameter of the bolts removed from the trailer should not exceed $12 \mathrm{~cm}$.

The weight of a single load (bolt) moved was determined by multiplying the volume of the bolt by the density of the wood after felling, which is $700 \mathrm{~kg} \times \mathrm{m}^{-3}[53,54]$.

To calculate the total estimated operating time of the hydraulic crane with which the trailer was equipped, the total number of loading and unloading cycles was determined. The number of loading and unloading cycles of the crane is a function of the payload capacity of the trailer, the capacity of the crane to carry a given size of load, and the volume of the piles on the cutting area, which always gives an integer [55]. This function can be written as follows (Equations (1) and (2)):

$$
\begin{gathered}
\mathrm{n}_{\text {load }}=\mathrm{np} \times \mathrm{ns}=\operatorname{Int}(\mathrm{Qt} \times \alpha \mathrm{t} / \mathrm{pv})+1 \times \operatorname{Int}(\mathrm{pv} / \mathrm{gv})+1(\mathrm{pcs}) \\
\mathrm{n}_{\text {unload }}=\operatorname{Int}(\mathrm{Qt} \times \alpha \mathrm{t} / \mathrm{gv})+1(\mathrm{pcs})
\end{gathered}
$$

where $\mathrm{n}_{\text {load }}$ is the number of loading cycles, $\mathrm{n}_{\text {unload }}$ is the number of unloading cycles, $\mathrm{np}$ is the number of piles prepared for removal (pcs), ns is the number of loading cycles per pile (pcs), Qt is payload of the trailer $\left(\mathrm{m}^{3}\right)$, pv is pile volume $\left(\mathrm{m}^{3}\right)$, gv is maximum grapple volume $=$ grapple working area $\times$ bolt length $\times$ proportion of solid timber (assumed 0.65 according to Gullberg [56]) $\left(\mathrm{m}^{3}\right)$, and $\alpha$ is payload coefficient of the trailer $(\alpha=0.9$ is assumed according to Nurek [55]).

The estimated times of mechanical loading and unloading did not include the times spent resting during manual loading and unloading (i.e., break times). Based on the observations made during the work and the time taken to prepare the place for the timber piles in the landing by the team unloading the timber manually, the time needed to perform this activity by one worker-the ATV unit operator-was determined. The time taken by the ATV unit driver was added to the working time of the helper in the process of laying out the bolts for the piles to be placed in the landing.

The time taken for loading individual piles using a hydraulic crane with a grapple was determined based on modified method time measurements for planning of production systems [57] and a model proposed by Gullberg [56] as "single pile loading", in which loading begins with an empty grapple. This is probably the most commonly observed mode of work for timber loading with cranes. If the distribution of various pile sizes is known, it is then possible to calculate the total time consumption by summarizing the time consumption for all piles. It was assumed that, as with the measured unloading time for manual work, the estimated time for unloading timber with a hydraulic crane was $7 \%$ longer than the loading time.

The cost associated with the use of machinery and equipment in both modes of operation was calculated based on the COST forest operations costing model proposed by Ackerman et al. in 2014 [58]. An annual use of the ATV unit for $800 \mathrm{~h}$ was assumed. Reduction of the time of annual ATV unit use caused a proportional increase in service life to 10 years. According to Spinelli and Magagnotti [59], this assumption for the cost calculation seems to better reflect the real use of machinery and equipment in small-scale, nonindustrial private forestry timber extraction. The data used for the calculation of the costs of machinery and equipment use are presented in Table 3.

Labor cost for one worker was assumed to be $15 \mathrm{EUR} \times \mathrm{h}^{-1}$, including indirect wage costs. This assumption should reflect the low use of small-scale logging and forwarding and the comparatively high labor costs of forestry in developed countries [59]. Fuel consumption was measured when the fuel tank was filled before starting the work and at the end of each work shift. Statistical analyses of independent variables, their conformity to normal distribution, analysis of variance, multiple regression models, and significance of differences in work time structure were performed using STATISTICA 12.5 PL package [60]. 
Table 3. Assumptions for the calculation of machinery and equipment costs.

\begin{tabular}{|c|c|c|c|c|}
\hline Type & Unit & $\begin{array}{l}\text { ATV CF MOTO } \\
\text { Allroad CF500 }\end{array}$ & $\begin{array}{l}\text { Trailer without a } \\
\text { Hydraulic Crane }\end{array}$ & $\begin{array}{l}\text { Trailer with a } \\
\text { Hydraulic Crane }\end{array}$ \\
\hline Investment cost * & EUR & 5820 & 1865 & 4135 \\
\hline Service life & years & 10 & 10 & 10 \\
\hline Time of use per year & hours & 800 & 800 & 800 \\
\hline Loan rate & $\%$ & 12 & 12 & 12 \\
\hline Insurance rate & $\%$ & 4 & 4 & 4 \\
\hline Fuel consumption & $\mathrm{dm}^{3} \times \mathrm{h}^{-1}$ & 0.75 & - & 0.875 \\
\hline Fuel price ${ }^{*}$ & $\mathrm{EUR} \times \mathrm{dm}^{-3}$ & 0.96 & - & 0.96 \\
\hline $\begin{array}{l}\text { Oils and lubricants } \\
\text { (\% of fuel costs) }\end{array}$ & $\%$ & 10 & 2 & 10 \\
\hline $\begin{array}{l}\text { Repair and maintenance } \\
\text { cost rate }\end{array}$ & $\%$ & 50 & 50 & 50 \\
\hline
\end{tabular}

${ }^{*}$ Costs and prices in euros (EUR) as of 15 February 2021; 1 EUR $=0.91 \mathrm{~GB} E=1.23$ US $\$=126.69 \mathrm{JPY}$.

\section{Results}

During the six work shifts analyzed, which covered a total of $45.3 \mathrm{~h}$, it was observed that more than 80 load rides (forwarding cycles) were made from the cutting area to the landing. The average forwarding distance was almost $500 \mathrm{~m}$, and the distance increased from about $230 \mathrm{~m}$ on the first working day to over $660 \mathrm{~m}$ on the last working day. More than 2750 bolts stacked on the cutting area in 283 piles were extracted. The total volume of the harvested timber slightly exceeded $86 \mathrm{~m}^{3}$, which represents $98 \%$ of the volume that was planned to be harvested in this stand. The average length of a work shift was $7.6 \mathrm{~h}$ $(6.8-8.1 \mathrm{~h})$. The detailed characteristics of timber loads, extraction distances, and duration of forwarding cycles are presented in Table 4.

Table 4. Characteristics of ATV unit loads, extraction distances, and times within forwarding cycles (number of forwarding cycles: 84).

\begin{tabular}{ccccccc}
\hline Variable & Unit & Mean & Sum & Min. & Max. & SD \\
\hline Number of bolts per load & $(\mathrm{pcs})$ & 33 & 2761 & 22 & 41 & 4.36 \\
Pile volume (within stand) & $\left(\mathrm{m}^{3}\right)$ & 0.325 & 86.060 & 0.124 & 0.833 & 0.099 \\
Load volume & $\left(\mathrm{m}^{3}\right)$ & 1.025 & 86.060 & 0.622 & 1.331 & 0.103 \\
Extraction distance & $(\mathrm{m})$ & 496 & 38073 & 235 & 665 & 142 \\
Work time within forwarding cycles & $(\mathrm{min})$ & 32.5 & 2718 & 19.9 & 67.3 & 9.9 \\
\hline
\end{tabular}

The average volume of one bolt was calculated as $0.032 \mathrm{~m}^{3}\left(0.010-0.133 \mathrm{~m}^{3}\right)$. The amount of timber forwarded during one work shift ranged from 12.35 to $15.55 \mathrm{~m}^{3}$ (average $\left.14.34 \mathrm{~m}^{3}\right)$.

\subsection{Work Time Structure}

The data on the actual duration of individual activities and operations during manual loading and the corresponding estimated duration during mechanical loading are presented in Table 5. The time of timber unloading in the landing accounted for the largest share of the work time structure (nearly 25\%). The timber loading time was shorter (by more than $23 \%$ ) because during this operation the workers did not pay attention to the accuracy of timber placement on the trailer. On the other hand, during unloading, a part of workers' time was spent on precise stacking and correcting the already stacked timber in accordance with the requirements for measuring and registering the piles. Time spent riding with a full load (forwarding timber) accounted for just over $9 \%$, and complementary work time activities accounted for a total of $20 \%$. Short breaks spent mostly resting during manual loading and unloading of timber accounted for almost $13 \%$. The remainder of the time (over 10\%) was taken for meal breaks. Due to occasional cases of minor malfunctions of the skidder set and the associated need to perform uncomplicated maintenance activities, work time accounted 
for just over 1\% (Table 5). Statistical analyses showed that the use of a trailer equipped with a hydraulic crane would enable significant reduction in the time spent on timber loading $(n=84 ; t$-Student $=40.232 ; p<0.001)$ and unloading $(n=84 ; Z=9.056 ; p<0.001)$, while a mechanically loaded trailer could reduce the proportion of time spent on these operations from $23.2 \%$ to $11.5 \%$ and from $24.7 \%$ to $12.5 \%$ of workplace time, respectively. In addition, the time spent for short breaks, in this case only for physiological needs, phone calls, etc., could be significantly reduced $(n=66 ; Z=2.041 ; p=0.004$ ) from $12.8 \%$ to $1.1 \%$ (Table 5 ).

Table 5. Duration of activities and operations throughout the experiment.

\begin{tabular}{|c|c|c|c|c|c|c|c|}
\hline \multirow[t]{2}{*}{ Activity/Operation } & \multirow[t]{2}{*}{$\begin{array}{l}\text { Group of } \\
\text { Time }\end{array}$} & \multicolumn{2}{|c|}{ Time of Manual Work } & \multicolumn{2}{|c|}{$\begin{array}{c}\text { Estimated Mechanical Work } \\
\text { Time }\end{array}$} & \multirow{2}{*}{$\begin{array}{c}\text { Difference } \\
\text { (hours) }\end{array}$} & \multirow{2}{*}{$\begin{array}{c}\begin{array}{c}\text { Change of } \\
\text { Activity Time * }\end{array} \\
(\%)\end{array}$} \\
\hline & & (hours) & $(\%)$ & (hours) & $(\%)$ & & \\
\hline Loading & MW & 10.5 & 23.2 & 2.7 & 11.5 & 7.8 & $\downarrow 74.3$ \\
\hline Forwarding & MW & 3.5 & 7.7 & 3.5 & 14.9 & - & - \\
\hline Unloading & MW & 11.2 & 24.7 & 2.9 & 12.4 & 8.3 & $\downarrow 74.1$ \\
\hline Ride without load & $\mathrm{CW}$ & 3.5 & 7.7 & 3.5 & 14.8 & - & - \\
\hline Ride during loading & $\mathrm{CW}$ & 4.1 & 9.1 & 4.1 & 17.1 & - & - \\
\hline Pile-place preparing & $\mathrm{CW}$ & 1.4 & 3.1 & 2.1 & 8.9 & -0.7 & $\uparrow 50.0$ \\
\hline Maintenance & MT & 0.5 & 1.1 & 0.5 & 2.3 & - & - \\
\hline Repairs & $\mathrm{RT}$ & 0.0 & 0.0 & 0.0 & 0.0 & - & - \\
\hline Rest and personal breaks & $\mathrm{RP}$ & 5.8 & 12.8 & 0.3 & 1.1 & 5.5 & $\downarrow 94.8$ \\
\hline Meal breaks & ME & 4.8 & 10.6 & 4.8 & 17.1 & - & - \\
\hline Total & WP & 45.3 & 100 & 24.5 & 100 & 20.8 & $\downarrow 45.9$ \\
\hline
\end{tabular}

* $\downarrow$ : decrease in duration compared to manual work; $\uparrow:$ increase in duration compared to manual work.

It was noted that during manual work, the longest time was spent in unloading at the landing and loading at the cutting area. Both operations took almost $48 \%$ of the workplace time, while mechanical loading and unloading accounted for more than $23 \%$ of the work place time. It seems that the use of a hydraulic crane trailer would allow more than $74 \%$ reduction in the time taken for timber loading and unloading under these operating conditions (Table 5). The data estimated for over 1420 timber loading and unloading operations carried out using the hydraulic crane are presented in Table 6.

Table 6. Estimated characteristics of ATV unit loading and unloading operations using a hydraulic grapple (number of operations: 1426).

\begin{tabular}{ccccccc}
\hline Variable & Unit & Mean & Sum & Min. & Max. & SD \\
\hline Number of bolts per grapple load & $(\mathrm{pcs})$ & 4 & 2761 & 3 & 6 & 1 \\
Number of operations per pile & $(\mathrm{pcs})$ & 3 & - & 1 & 7 & 1 \\
$\quad$ (within stand) & $(\mathrm{pcs})$ & 9 & - & 5 & 11 & 1 \\
Number of operations per one load & $(\mathrm{min})$ & 1.9 & 163.5 & 1.2 & 3.2 & 0.4 \\
Time of loading per load & $(\mathrm{min})$ & 2.1 & 176.4 & 1.1 & 3.5 & 0.4 \\
Time of unloading per load &
\end{tabular}

In addition, a significant reduction of almost $95 \%$ can be achieved in short breaks. Increased work time would be expected when a single person manually performs site preparation and placement of pads under timber piles (Table 5). If a hydraulic crane was used to prepare these pads, the time would likely be reduced. Using a set with a small forestry trailer equipped with a hydraulic crane for the work would reduce the total time taken to transport timber under these field conditions from the stand to the landing by almost $46 \%$.

\subsection{Forwarding Productivity for Manual Loading and Unloading}

The gross productivity during workplace time ranged from 1.68 to $2.05 \mathrm{~m}^{3} \times \mathrm{SMH}^{-1}$ (during the last and first day of work, respectively), while net productivity during productive work time ranged from 2.23 to $2.75 \mathrm{~m}^{3} \times \mathrm{PMH}^{-1}$. 
The relationships between the net productivity of the actual forwarding cycle at manual loading and the number of bolts to be loaded, the forwarding distance, and the volume of the forwarded load were presented using a multiple regression model (Equation (3)). The parameters of the model are shown in Table 7.

$$
\mathrm{FCP}_{\text {manual }}=0.695-0.005 \times \mathrm{a}-0.001 \times \mathrm{b}+2.375 \times \mathrm{c}\left(\mathrm{m}^{3} \times \mathrm{PMH}^{-1}\right)
$$

where FCP is the forwarding cycle productivity, $a$ is the number of bolts (pcs), b is the forwarding distance $(\mathrm{m})$, and $\mathrm{c}$ is the load volume $\left(\mathrm{m}^{3}\right)$.

Table 7. Regression analysis: productivity of a forwarding cycle (manual loading and unloading).

\begin{tabular}{|c|c|c|c|c|c|}
\hline \multicolumn{6}{|c|}{ Equation Parameters: $R=0.77 ; R^{2}=0.59 ; F=36.76 ; p<0.001 ;$ Estimation Error $=0.232$} \\
\hline \multicolumn{6}{|c|}{ Parameters of Independent Variables: } \\
\hline & $\beta$ & SD & $\begin{array}{l}\text { Coefficients of } \\
\text { Regression }\end{array}$ & $t$ & $p$ \\
\hline Absolute term & - & 0.29 & 0.695 & 2.43 & 0.018 \\
\hline a (bolts number) & -0.06 & 0.01 & -0.005 & -0.70 & 0.486 \\
\hline $\mathrm{b}$ (forwarding distance) & -0.38 & 0.00 & -0.001 & -5.22 & $<0.001$ \\
\hline C (load volume) & 0.69 & 0.28 & 2.375 & 8.51 & $<0.001$ \\
\hline
\end{tabular}

The model presented in Equation (1) explains almost $60 \%$ of the variation in the calculated forwarding cycle productivity. The values of the standardized regression coefficient $\beta$ indicate that when loading was performed manually, the load volume had the strongest effect on the performance of forwarding cycle, followed by the forwarding distance. On the other hand, the number of bolts in the load, which is closely related to the number of work movements of the workers who loaded and then unloaded the timber, had the smallest or non-significant effect on the productivity of forwarding cycle.

\subsection{Forwarding Productivity for Mechanical Loading and Unloading}

The gross productivity during workplace time ranged from 2.80 to $5.00 \mathrm{~m}^{3} \times \mathrm{SMH}^{-1}$ (during the last and first day of operation, respectively), while net productivity during productive work time oscillated between 3.70 and $5.82 \mathrm{~m}^{3} \times \mathrm{PMH}^{-1}$.

A multiple regression model describing the estimated net productivity of the forwarding cycle in productive work time under mechanical loading is presented using Equation (4). The parameters of the model are shown in Table 8.

$$
\mathrm{FCP}_{\text {mechanical }}=1.83-0.002 \times \mathrm{a}-0.002 \times \mathrm{b}+4.196 \times \mathrm{c}\left(\mathrm{m}^{3} \times \mathrm{PMH}^{-1}\right)
$$

where FCP is the forwarding cycle productivity, a is the number of grapple loads (pcs). and $\mathrm{b}$ and $\mathrm{c}$ represent the symbols as in Equation (1).

\begin{tabular}{|c|c|c|c|c|c|}
\hline \multicolumn{6}{|c|}{ Equation Parameters: $R=0.76 ; R^{2}=0.57 ; F=29.54 ; p<0.001 ;$ Estimation Error $=0.488$} \\
\hline \multicolumn{6}{|c|}{ Parameters of Independent Variables: } \\
\hline & $\beta$ & SD & $\begin{array}{l}\text { Coefficients of } \\
\text { Regression }\end{array}$ & $t$ & $p$ \\
\hline Absolute term & - & 0.60 & 1.830 & 3.07 & 0.003 \\
\hline $\mathrm{a}$ (number of grapple loads) & -0.01 & 0.19 & -0.002 & -0.01 & 0.990 \\
\hline $\mathrm{b}$ (forwarding distance) & -0.45 & 0.00 & -0.002 & -5.54 & $<0.001$ \\
\hline C (load volume) & 0.61 & 1.72 & 4.196 & 2.44 & 0.017 \\
\hline
\end{tabular}

Table 8. Regression analysis: productivity of a forwarding cycle (mechanical loading and unloading).

The model presented in Equation (4) explains over 55\% of the variation observed in the predicted productivity of the forwarding cycle. The values of the standardized regression 
coefficients $\beta$ indicate that when a hydraulic crane is used for loading, analogous to manual loading, the volume of the trailer loads would have the strongest effect on the productivity of the forwarding cycle. Similar to manual loading, forwarding distance would influence the productivity achieved (Figure 5). On the other hand, the number of hydraulic grapple loads would have the least or non-significant effect on the productivity of the forwarding cycle. The shaded portion in the figure shows the predicted forwarding productivity for values other than those recorded during field testing.

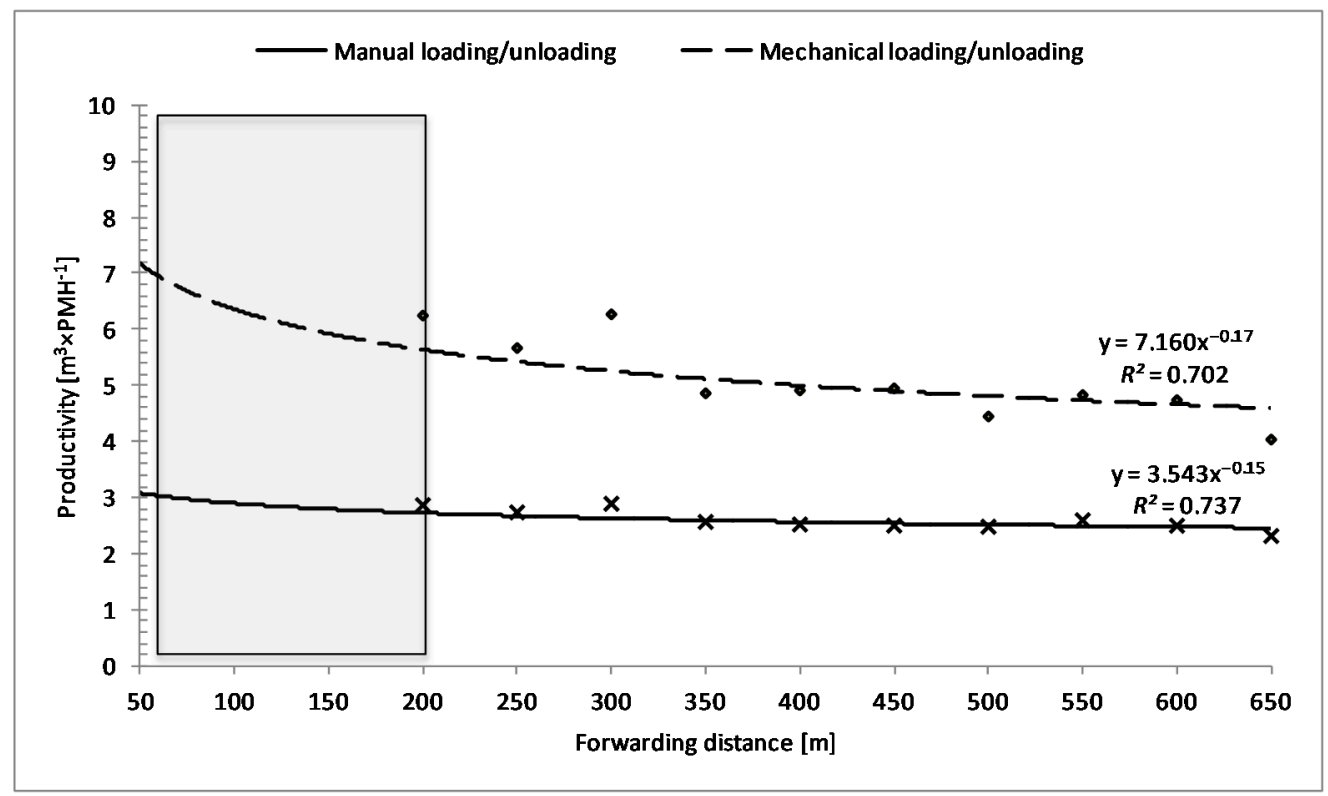

Figure 5. Net productivity of timber extraction using ATV depending on forwarding distance.

For both manual and mechanical loading, trailer load volume was found to have the greatest and most significant effect on the productivity of the forwarding cycle. Therefore, the dependence of forwarding net productivity in productive work time on this variable is shown in Figure 6.

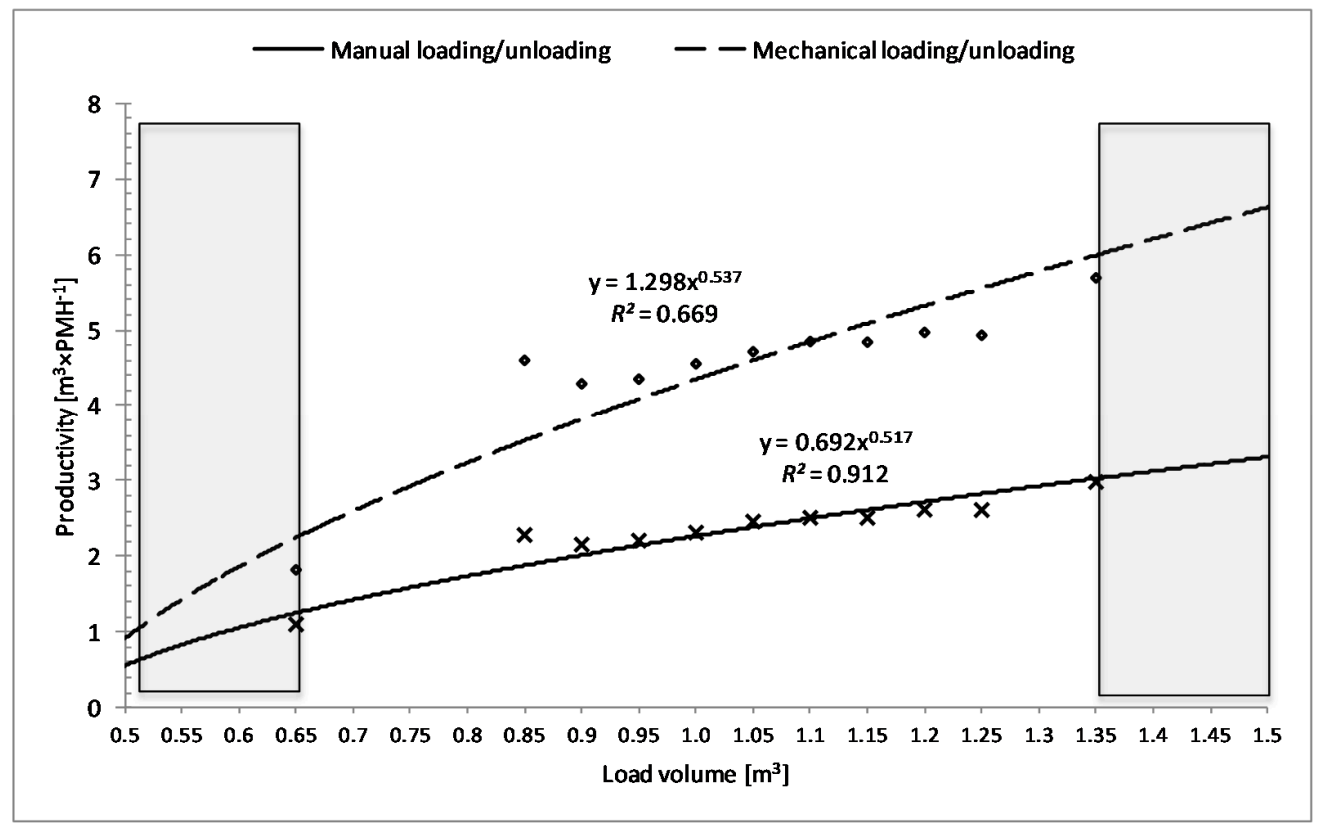

Figure 6. Net productivity of timber extraction using ATV depending on load volume of the trailer. 


\subsection{Costs of Timber Forwarding}

Based on the total time of timber forwarding and the total amount of timber taken to the landing, the total operating costs of the forwarding unit at manual work were estimated at 2.28 EUR $\times \mathrm{SMH}^{-1}$, while at mechanical loading and unloading the costs amounted to $3.71 \mathrm{EUR} \times \mathrm{SMH}^{-1}$. The unit costs associated with the use of the described machines and equipment at manual loading and unloading were determined at $0.90 \mathrm{EUR} \times \mathrm{m}^{-3}$ in productive work time and 1.20 EUR $\times \mathrm{m}^{-3}$ in workplace time. The use of a trailer with a hydraulic crane allowed a reduction in unit costs to 0.78 and $1.02 \mathrm{EUR} \times \mathrm{m}^{-3}$, respectively. However, the total unit costs (including labor costs) associated with manual loading were 6.77 EUR $\times \mathrm{m}^{-3}$ in productive work time and 9.09 EUR $\times \mathrm{m}^{-3}$ in workplace time. The costs of timber forwarding with mechanical loading and unloading were $2.36 \mathrm{EUR} \times \mathrm{m}^{-3}$ in productive work time and $3.10 \mathrm{EUR} \times \mathrm{m}^{-3}$ in workplace time. Figure 7 shows the unit costs of timber forwarding with an ATV depending on the distance to the landing.

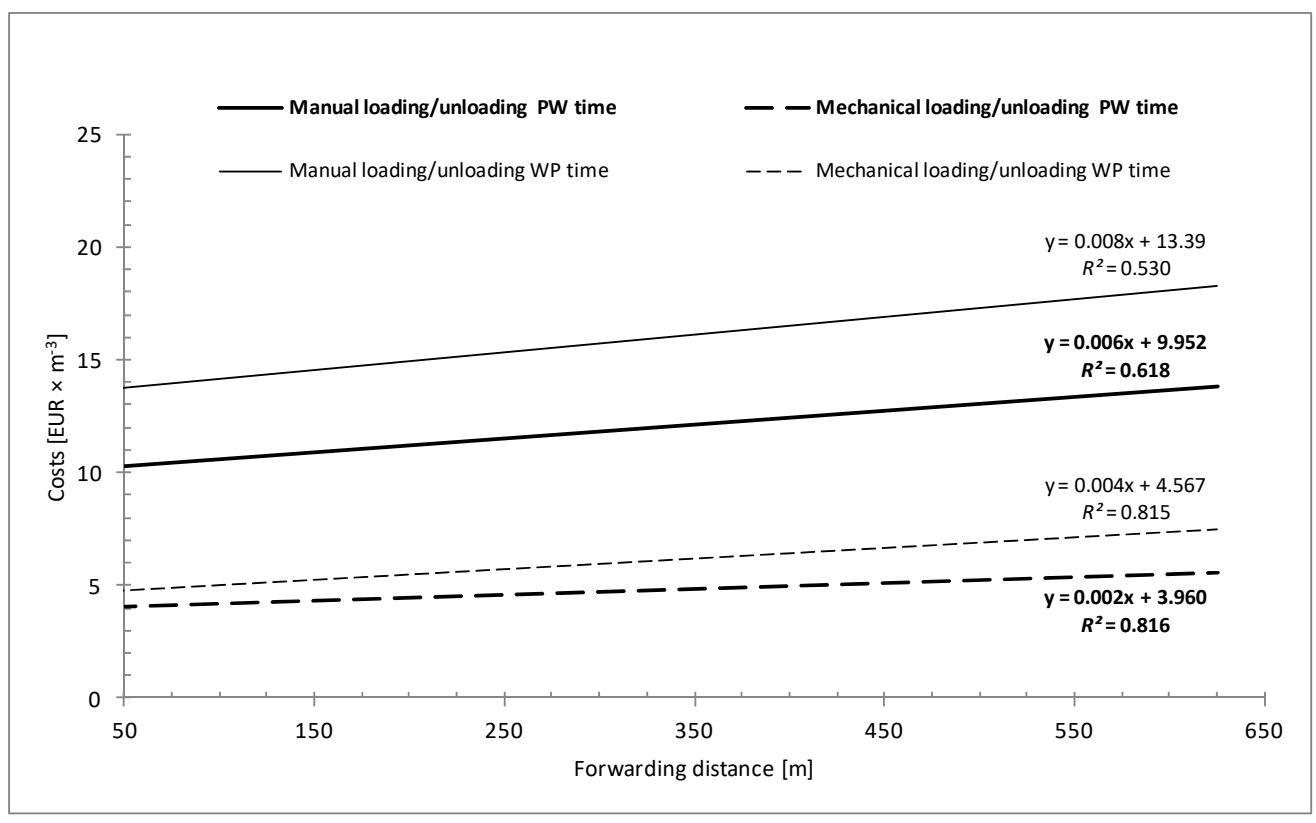

Figure 7. Costs of timber extraction using ATV depending on forwarding distance.

\subsection{Risk of Musculoskeletal Strain}

The performed analyses indicated that loading and unloading of timber accounted for $43.9 \%$ of the work shift time. For the calculation of the risk indices, it was assumed that loading on the trailer required lifting to the height of the trailer stakes $(1.1 \mathrm{~m})$ and unloading involved stacking timber below the workers' shoulder line $(1.3 \mathrm{~m})$. The average load weight was found to be $22 \mathrm{~kg}\left(\mathrm{~d}_{1 / 2}=12 \mathrm{~cm}\right)$ and ranged from 7.5 to $120 \mathrm{~kg}$. The workers performed an average of 4-5 lifts per minute without the use of assistive tools (coupling: fair). The calculated value of CLI was 2.5, and the corresponding value of FILI was 3.2. These values clearly indicate that the weight of loads handled often exceeded the recommended weight and that the associated risk of injury was high.

The calculations showed that the recommended load weight per individual employee should not exceed several kilograms (STRWL $=14.5 \mathrm{~kg}$, FIRWL $=17.2 \mathrm{~kg}$ ). When using mechanical devices (e.g., a mounted hydraulic crane) for loading and unloading, lever manipulation is performed in a free-standing position and manual transport is limited only to placing or improving two rows of timber stacking pads, placed parallel to the direction of the ride. The described form of organization of transport work is primarily characterized by reduction of frequency and duration of transport operations (moving timber bolts) involving, on average, eight lifts per shift with a slight increase in transport 
distance. Replacing manual work with mechanical work reduces the risk of injury resulting from manual unloading to a necessary minimum $(\mathrm{CLI}=0.57, \mathrm{FILI}=0.78)$.

\section{Discussion}

\subsection{Work Time Structure}

The performed analyses indicate that, with manual loading and unloading, nearly $25 \%$ of the work time was accounted for by the miniforwarder rides, which included not only loaded and unloaded rides but also the movement associated with timber loading onto the trailer. In contrast, with mechanical loading, the rides would account for nearly $47 \%$ of the work time on the work surface. However, considering the loading and unloading operations and rides within productive work time, their share in both technology variants would be similar-more than $72 \%$ for manual work and more than $70 \%$ for mechanical loading. On the other hand, the time spent by workers on rest and personal breaks and meals accounted for more than $23 \%$ of the working time in both manual and mechanical operations. Similar results were found in field tests conducted in the United Kingdom [44]. It was reported that, during the work of one ATV-miniforwarder operator who manually loaded and unloaded timber (with an average bolt volume of $0.023 \mathrm{~m}^{3}$ ), the time taken for breaks and rest accounted for $22 \%$ of the time on the cutting area. On the other hand, during the work of an Iron Horse-based microforwarder operator moving on foot, the time taken for breaks and rest already accounted for $33 \%$ of the time on the cutting area [61].

In the case of mechanical loading considered in the present study, the time for rest and other breaks would account for more than $18 \%$. This is similar to the results obtained during field testing of Alstor and Scorpion 1205 miniforwarders, and the results of testing of Entracon LogLander LL85 miniforwarder, in which rest periods and other break times accounted for $15 \%[43,45]$ and $16-19 \%$, respectively [59].

\subsection{Productivity of Manual Loading and Unloading}

The calculated gross productivity of manually loaded forwarding during workplace time (1.68-2.05 $\left.\mathrm{m}^{3} \times \mathrm{SMH}^{-1}\right)$ at an extraction distance of 235-665 m during individual work shifts was very close to the productivity estimated from field tests conducted by the UK Forestry Commission [44]. For example, when an ATV unit was used for forwarding timber on flat terrain over a distance of $100 \mathrm{~m}$, with an average bolt volume of $0.023 \mathrm{~m}^{3}$, the productivity ranged, depending on terrain availability (e.g., the existence of obstacles along the operating trails), from $1.45 \mathrm{~m}^{3} \times \mathrm{SMH}^{-1}$ in more difficult terrain (80\% of forwarding distance within the stand (cutting site) and $20 \%$ along extraction routes) to $2.05 \mathrm{~m}^{3} \times \mathrm{SMH}^{-1}$ in easier conditions (50\% of forwarding distance within the stand (cutting site) and $50 \%$ along extraction routes) (SMH corresponds to productivity during work place time). On the other hand, an ATV unit with a trailer equipped with a loading arch and cable winch allowed achieving a forwarding productivity of 1.3-1.4 $\mathrm{m}^{3} \times \mathrm{SMH}^{-1}$ over an extraction distance of $100 \mathrm{~m}$ and with an average bolt volume of $0.042 \mathrm{~m}^{3}$. In other tests, at the same extraction distance of $100 \mathrm{~m}$ and with an average bolt volume of about $0.02 \mathrm{~m}^{3}$, the forwarding productivity with Iron Horse-based forwarding-unit ranged from 1.90 to $2.30 \mathrm{~m}^{3} \times \mathrm{SMH}^{-1}$ [61] and even $2.47 \mathrm{~m}^{3} \times \mathrm{SMH}^{-1}$ at an average forwarding distance of $320 \mathrm{~m}$ [62]. In the present study, with an average bolt volume of $0.032 \mathrm{~m}^{3}$, the estimated forwarding productivity per $100 \mathrm{~m}$ was $2.17 \mathrm{~m}^{3} \times \mathrm{SMH}^{-1}(50 \%$ forwarding distance within the stand and $50 \%$ along the extraction routes). This is probably because the work was performed by two people and that the bolts were loaded from small, irregular piles of timber, prepared earlier by chainsaw operator. Such a method of timber preparation mainly reduced the time of transitions of workers compared to the situation when the bolts would lie spread out in their delimbing and thinning places. According to Stempski [63], even with mechanical loading, the share of time needed to pick up lying bolts directly from their delimbing and thinning locations may increase significantly, by $47-48 \%$ compared to that needed to collect bolts in irregular piles near extraction routes. 


\subsection{Productivity of Mechanical Loading and Unloading}

The estimated gross productivity of mechanically loaded forwarding during workplace time ranged between 1.88 and $3.10 \mathrm{~m}^{3} \times \mathrm{SMH}^{-1}$ at a distance of $235-665 \mathrm{~m}$. However, at the extraction distance of $100 \mathrm{~m}$, the productivity was estimated at $3.31 \mathrm{~m}^{3} \times \mathrm{SMH}^{-1}$. This result can be considered reliable in the light of previously published studies. Similar data were recorded in field tests conducted using an Alstor miniforwarder equipped with a forestry trailer and a hydraulic crane [43]. Under similar field conditions (slope 5-20\%) and with an average bolt volume of $0.038-0.044 \mathrm{~m}^{3}$ and an average distance from the landing of 95-195 $\mathrm{m}$, the forwarding productivity during workplace time was determined at $3.27-3.35 \mathrm{~m}^{3} \times \mathrm{SMH}^{-1}$. On the other hand, in operational research on a Scorpion miniforwarder having a trailer capacity of 2.5 tons, which extracted bolts over a distance of $\sim 150 \mathrm{~m}$ in flat terrain without obstacles, the productivity was determined at $4.23 \mathrm{~m}^{3} \times \mathrm{SMH}^{-1}$ [45]. It should be noted, however, that the average bolt volume in the aforementioned study was $0.048 \mathrm{~m}^{3}$. Spinelli and Magagnotti [59] reported that, when bolts with an average volume of 0.023-0.038 $\mathrm{m}^{3}$ were forwarded using an Entracon LogLander LL85 miniforwarder having a trailer capacity of 4.5 tons, the productivity of timber forwarding was $3.1-3.8 \mathrm{~m}^{3} \times \mathrm{SMH}^{-1}$ at an extraction distance of 360-405 m (50\% forwarding distance within the cutting site and $50 \%$ along extraction routes). In the present study, the forwarding productivity achieved may have been influenced by the arrangement of bolts on the cutting site in irregular piles and by the bolt volume ( $0.12-0.83 \mathrm{~m}^{3}$ ) (Tables 7 and 8 ). The important role played by this factor, especially during timber loading, was also emphasized by Väätäinen et al. [64].

\subsection{Costs of Timber Forwarding}

The costs of timber forwarding calculated in this study indicate that the operating costs of a forwarding unit with a trailer equipped with a hydraulic crane would be more than $60 \%$ higher compared to that of a unit with a trailer without a crane. However, the unit costs of timber forwarding with mechanical loading and unloading would be lower in both productive work time and workplace time by about $15 \%$. In turn, the total unit costs (including labor costs) of forwarding with manual loading and unloading were almost threefold higher than that of forwarding with a trailer equipped with a hydraulic crane in both productive work time and workplace time. In the case of timber forwarding with a trailer without a hydraulic crane over a distance of $100 \mathrm{~m}$, the estimated unit costs in workplace time were $14.09 \mathrm{EUR} \times \mathrm{m}^{-3}$ for a two-person operation. The results of field tests conducted by the British Forestry Commission [44,61] indicated that these costs can be reduced to $6.74-8.75 \mathrm{EUR} \times \mathrm{m}^{-3}$ depending on terrain availability. It should be emphasized, however, that this applies only to one-person work and not to two-person work as in the present study. On the other hand, the unit costs of forwarding in workplace time using a trailer equipped with a hydraulic crane over a distance of $100 \mathrm{~m}$ would be 4.97 EUR $\times \mathrm{m}^{-3}$. Similar costs were indicated for timber forwarding in thinning stands using Alstor and Scorpion mini-forwarders $[43,45]$. Under comparable field conditions, the costs amounted to less than $5.10 \mathrm{EUR} \times \mathrm{m}^{-3}$, and, in the stands of regrowth, they amounted to about $5.20 \mathrm{EUR} \times \mathrm{m}^{-3}$.

\subsection{Injuries' Risk}

In most countries of the European Union, it is accepted that the weight of a load transported by a person should not exceed $30 \mathrm{~kg}$, and, in individual cases, the weight should not be more than $105 \mathrm{~kg}[65,66]$. Although the results obtained in this study show that during the analyzed work shifts $75 \%$ of the bolts were characterized by a lower weight than the permissible one $(30 \mathrm{~kg})$, several bolts (14 pieces) had a weight of more than $100 \mathrm{~kg}$. Therefore, during manual transport, it is advisable to prepare workers physically and in terms of work techniques, as well as to inform them about the risks and consequences of overloading and possible injuries. The values of transported load weights (STRWL $=14.5 \mathrm{~kg}$, FIRWL $=17.2 \mathrm{~kg}$ ) estimated in this study indicate that the central diameter of the lifted and lowered pine bolt having a length of $2.5 \mathrm{~m}$ should not 
exceed $14.5 \mathrm{~cm}$, in order to minimize the risks of musculoskeletal injuries associated with overloading in workers in a two-person team.

The use of small forest trailers equipped with a hydraulic crane not only ensures higher productivity and cost effectiveness (inter alia, due to the involvement of only one employee), but also reduces the risk of injury. Transport operations are carried out in a freestanding position, and the operator is forced only to a limited extent to manually lift and lower the bolts, thus avoiding the handling of the heaviest loads. In addition to reducing the individual risk resulting from the physical condition of the operator, work safety may be improved by using good-quality hooks or self-locking tongs for timber, which guarantee a secure grip, reduce the lifting height, and ultimately significantly decrease (even by a few percentage points) the energy expended for this type of work [67].

\section{Conclusions}

During manual work, the longest time was spent on unloading at the landing and loading at the cutting area. Using a trailer with a hydraulic crane would significantly reduce the duration of these operations. In addition, short breaks would be considerably reduced. On the other hand, it would take longer to prepare the pads for timber piles. The total time of forwarding with a set of trailers equipped with a hydraulic crane would be almost halved. The calculated average productivity of timber forwarding with manual loading and unloading during productive work time was almost twice lower than that of forwarding with mechanical loading and unloading. Thus, the time consumption within productive work time for forwarding with a trailer unit without a hydraulic crane was $85 \%$ higher. For both manually and mechanically loaded forwarding, the productivity of forwarding cycles was most strongly influenced by the volume of the loads being moved, followed by the forwarding distance. The total unit costs (including labor costs) associated with manual loading were nearly three times higher than that of mechanically loaded forwarding. The risk of musculoskeletal strain is high in the case of manual loading and unloading. The use of a hydraulic crane for loading and unloading allows for a significant reduction of this risk, due to the reduction of unfavorable manual transport operations (lifting and placing the bolts in a forced body position).

Author Contributions: Conceptualization, A.S., G.S. and P.K.; methodology, A.S., D.K. and K.L.; writing-original draft preparation, A.S. and K.L.; writing-review and editing, A.S., D.K., K.L. and G.S.; visualization, A.S. and P.K. All authors have read and agreed to the published version of the manuscript.

Funding: This research was funded by Ministry of Education and Science for the University of Agriculture in Krakow in 2021.

Institutional Review Board Statement: Not applicable.

Informed Consent Statement: Not applicable.

Data Availability Statement: The study did not report any data.

Conflicts of Interest: The authors declare no conflict of interest.

\section{References}

1. Harrison, S.; Herbohn, J.; Niskanen, A. Non-industrial, smallholder, small-scale and family forestry: What's in a name? Small Scale For. Econ. Manag. Policy 2002, 1, 1-11. [CrossRef]

2. Lindroos, O.; Lidestav, G.; Nordfjell, T. Swedish non-industrial private forest owners: A survey of self-employment and equipment investments. Small Scale For. Econ. Manag. Policy 2005, 4, 409-425. [CrossRef]

3. Gołos, P. Private forests in Poland-The results of the questionnaire surveys covering the network of test forest holdings. Folia For. Pol. 2011, 53, 25-42.

4. GUS. Statistical Yearbook of Forestry; Główny Urząd Statystyczny Statistics Poland: Warsaw, Poland, 2020.

5. Herbohn, J. Small-Scale Forestry-Is It Simply a Smaller Version of Industrial (Large-Scale) Multiple Use Foresty? Small Scale For. Rural. Dev. Intersect. Ecosyst. Econ. Soc. 2006, 158-163.

6. Glazar, K.; Maciejewska, H. Struktura czasu i wydajność pozyskiwania i zrywki drewna w drzewostanach sosnowych przy użyciu harwardera Buffalo Dual. Inżynieria Rolnicza 2008, 12, 111-118. 
7. Mederski, P. A comparison of harvesting productivity and costs in thinning operations with and without midfield. For. Ecol. Manag. 2006, 224, 286-296. [CrossRef]

8. Mederski, P.; Bembenek, M.; Karaszewski, Z.; Lacka, A.; Szczepanska-Alvarez, A.; Rosinska, M. Estimating and modelling harvester productivity in pine stands of different ages, densities and thinning intensities. Croat. J. For. Eng. 2016, 37, $27-36$.

9. Mederski, P.; Venanzi, R.; Bembenek, M.; Karaszewski, Z.; Rosinska, M.; Pilarek, Z.; Luchenti, I.; Surus, M. Designing thinning operations in 2nd age class pine stands economic and environmental implications. Forests 2018, 9, 12. [CrossRef]

10. Moskalik, T. Rozwój technik i technologii maszynowego pozyskiwania drewna (Development of machine technologies within timber harvesting). Sylwan 2002, 146, 31-37.

11. Moskalik, T.; Borz, S.A.; Dvořak, J.; Ferencik, M.; Glushkov, S.; Muiste, P.; Lazdiň̌, A.; Styranivsky, O. Timber harvesting methods in Eastern European countries: A review. Croat. J. For. Eng. 2017, 38, 231-241.

12. Więsik, J. Urządzenia Techniczne w Produkcji Leśnej. Tom 2-Maszyny i Urządzenia do Pozyskiwania i Transportu Drewna (Technical Devices in Forest Production. Vol. 2. Machines and Devices for Timber Harvesting and Transportation), 1st ed.; Wydawnictwo SGGW: Warszawa, Poland, 2015; Volume 2.

13. Mederski, P.S.; Borz, S.A.; Duka, A.; Lazdins, A. Challenges in forestry and forest engineering-Case studies from four countries in East Europe. Croat. J. For. Eng. 2021, 42, 117-134. [CrossRef]

14. Sowa, J.; Kulak, D.; Szewczyk, G. Costs and efficiency of timber harvesting by NIAB 5-15 processor mounted on a farm tractor. Croat. J. For. Eng. 2007, 28, 177-184.

15. Leszczyński, K.; Stańczykiewicz, A. Workload analysis in logging technology employing a processor aggregated with a farm tractor. For. Syst. 2015, 24, 8. [CrossRef]

16. Gorzelak, A. Gospodarowanie w Lasach Drobnej Własności (Management within Private Forests), 1st ed.; Forest Research Institute: Warszawa, Poland, 2001.

17. Marenče, J.; Krč, J. Possibilities of using small tractors for forestry operations on private property. Croat. J. For. Eng. J. Theory Appl. For. Eng. 2016, 37, 151-162.

18. Stańczykiewicz, A. Prawdopodobieństwo Wystapienia Szkód w Odnowieniach Podokapowych Wskutek Pozyskiwania Drewna oraz Model ich Szacowania (The Probability of Occurrence of Damage to Regeneration under Canopy due to Timber Harvesting and The Model of its Evaluating), 1st ed.; Zeszyty Naukowe Uniwersytetu Rolniczego im. Hugona Kołłąaja w Krakowie: Kraków, Poland, 2018; Volume 541.

19. Szewczyk, G. Czasochłonność zrywki drewna wyciagarkami zagregowanymi z pilarkami spalinowymi w drzewostanach trzebieżowych. Sylwan 2011, 155, 401-412.

20. Savelli, S.; Cavalli, R.; Baldini, S.; Picchio, R. Small scale mechanization of thinning in artificial coniferous plantation. Croat. J. For. Eng. 2010, 31, 11-21.

21. Pierskalla, C.D.; Schuett, M.A.; Thompson, K.A. Management perceptions of off-highway vehicle use on national forest system lands in Appalachia. North. J. Appl. For. 2011, 28, 208-213. [CrossRef]

22. Vusić, D.; Šušnjar, M.; Marchi, E.; Spina, R.; Žecić, Ž.; Picchio, R. Skidding operations in thinning and shelterwood cut of mixed stands-Work productivity, energy inputs and emissions. Ecol. Eng. 2013, 61, 216-223. [CrossRef]

23. Stempski, W.; Pilarek, Z. Charakterystyka zrywki drewna miniforwarderem VIMEK 606 D. Tech. Rol. Ogrod. Leśna. 2012, 3, 26-28.

24. Russell, F.; Mortimer, D. A Review of Small-Scale Harvesting Systems in Use Worldwide and Their Potential Application in Irish Forestry, 1st ed.; COFORD: Dublin, Ireland, 2005.

25. Hutchison, I. Mechanised minimal-impact extraction systems. J. For. 1995, 89, 27-32.

26. Forestry Commission. Outdoor workshops-Review of small scale harvesting equipment. For. Res.-Tech. Dev. Branch 2005, 08/05, 13.

27. Vaughan, D.; Mackes, K. Characteristics of Colorado forestry contractors and their role in current forest health issues. For. Prod. J. 2015, 65, 217-225. [CrossRef]

28. Goldcamp, E.M.; Myers, J.; Hendricks, K.; Layne, L.; Helmkamp, J. Nonfatal all-terrain vehicle-related injuries to youths living on farms in the United States. J. Rural Health 2006, 22, 308-313. [CrossRef] [PubMed]

29. Fragar, L.; Pollock, K.; Temperley, J. A National Strategy for Improving ATV Safety on Australian Farms; Rural Industries Research and Development Corporation: Barton/Kingston, ATC, Australia, 2005.

30. Ladrach, W.E. Harvesting and comparative thinning alternatives in Gmelina Arborea plantations. New For. 2004, 28, 255-268. [CrossRef]

31. Hedderick, D. Small woodlot harvesting: A Guide for Landowners, Land Managers and Forest Products Operators. Available online: http:/ / www.dnr.state.md.us/irc/docs/00013497.pdf (accessed on 17 November 2007).

32. Masson, S.; Greek, M. Woodlot Management Home Study Course-Module 12—Small Scale Harvesting Equipment, 1st ed.; Nova Scotia Department of Natural Resources: Halifax, NS, Canada, 2006.

33. Kranvagnar Från Avestavagnen, Skogsvagnar, Flakvagnar och Vedvagnar. Available online: http://avestavagnen.se/ (accessed on 7 November 2021).

34. Kellfri-Enkelt att Bruka. Available online: https:/ /www.kellfri.se/ (accessed on 7 November 2021).

35. Kranman ABISkördare, Miniskotare, ATV-Vagnar Från Sverige. Available online: https://kranman.com/ (accessed on 7 November 2021).

36. Vreten. Available online: https://www.vreten.se/ (accessed on 7 November 2021). 
37. Lindroos, O.; La Hera, P.; Häggström, C. Drivers of advances in mechanized timber harvesting-A selective review of technological innovation. Croat. J. For. Eng. 2017, 2, 243-258.

38. Grzebieta, R.; Simmons, M.K.; McIntosh, A. Final Project Summary Report, Conclusion and Recommendation 4 Transport and Road Safety (TARS). In The Quad Bike Performance Project; University of New South Wales: Sydney, Australia, 2015 ; p. 96.

39. Myers, M.L. All-terrain vehicle safety-Potential effectiveness of the quadbar as a crush prevention device. Safety 2016, 2, 3. [CrossRef]

40. Edlund, B.; Lindroos, O.; Nordfjell, T. The effect of rollover protection systems and trailers on quad bike stability. Int. J. For. Engi. 2020, 31, 95-105. [CrossRef]

41. Meadows, D.; Foltz, R.; Geehan, N. Effects of All-Terrain Vehicles on Forested Lands and Grasslands; U.S. Department of Agriculture, Forest Service, Technology and Development Center: San Dimas, CA, USA, 2008.

42. Chin, A.; Rohrer, D.M.; Marion, D.A.; Clingenpeel, J.A. Effects of All-Terrain Vehicles on Stream Dynamics; U.S. Department of Agriculture, Forest Service, Southern Research Station: Asheville, NC, USA, 2004; pp. 292-296.

43. Forestry Commission. The ALSTOR mini-forwarder. For. Res.-Tech. Dev. Branch 2001, 09/06, 4.

44. Forestry Commission. ATC forwarder. For. Res.-Tech. Dev. Branch 2002, 9, 5.

45. Forestry Commission. The SCORPION 1205 mini forwarder. For. Res.-Tech. Dev. Branch 2002, 9, 4.

46. Bank Danych o Lasach (Forest Data Bank). Available online: https://www.bdl.lasy.gov.pl/portal/mapy-en (accessed on 15 November 2021).

47. Malinen, J.; Laitila, J.; Vaatainen, K.; Viitamaki, K. Variation in age, annual usage and resale price of cut-to-length machinery in different regions of Europe. Int. J. For. Eng. 2016, 27, 95-102. [CrossRef]

48. Pajkos, M.; Klvac, R.; Neruda, J.; Mishra, P.K. Comparative time study of conventional cut-to-length and an integrated harvesting method-a case study. Forests 2018, 9, 194. [CrossRef]

49. Bjorheden, R.; Thompson, M.A. An International Nomenclature for Forest Work Study; University of Maine: Orono, ME, USA, 1995; pp. 190-215.

50. Szewczyk, G. Model Strukturalny Dynamiki Zmienności Pracy na Wybranych Stanowiskach Roboczych w Pozyskiwaniu i Zrywce Drewna (Structural Model of Work Variability Dynamics at Selected Work Sites in Timber Harvesting and Skidding), 1st ed.; Zeszyty Naukowe Uniwersytetu Rolniczego im. Hugona Kołłątaja w Krakowie: Kraków, Poland, 2014; Volume 522.

51. Waters, T.R.; Putz-Anderson, V.; Garg, A.; Fine, L.J. Revised NIOSH equation for the design and evaluation of manual lifting tasks. Ergonomics 1993, 36, 749-776. [CrossRef] [PubMed]

52. Dempsey, P. Usability of the revised NIOSH lifting equation. Ergonomics 2002, 45, 817-828. [CrossRef]

53. Krzysik, F. Nauka o Drewnie (Wood Science), 1st ed.; Państwowe Wydawnictwo Naukowe: Warszawa, Poland, 1975.

54. Tomczak, A.; Jelonek, T.; Jakubowski, M. Density of scots pine (Pinus Sylvestris L.) wood as an indicator of tree resistance to strong winds. Sylwan 2013, 157, 539-545.

55. Nurek, T. Wpływ sposobu przygotowania stosów na efektywność zrywki drewna forwarderem (The influence of the method of preparing piles on the effectiveness of harvesting wood with a forwarder). Przegląd Tech. Rol. Leśnej 2002, 11, 16-21.

56. Gullberg, T. A deductive time consumption model for loading shortwood. J. For. Eng. 1997, 8, 35-44. [CrossRef]

57. Christmansson, M.; Falck, A.-C.; Amprazis, J.; Forsman, M.; Rasmusson, L.; Kadefors, R. Modified method TTme measurements for ergonomic planning of production systems in the manufacturing industry. Int. J. Prod. Res. 2000, 38, 4051-4059. [CrossRef]

58. Ackerman, P.; Belbo, H.; Eliasson, L.; de Jong, A.; Lazdins, A.; Lyons, J. The COST model for calculation of forest operations costs. Int. J. For. Eng. 2014, 25, 75-81. [CrossRef]

59. Spinelli, R.; Magagnotti, N. Performance and cost of a new mini-forwarder for use in thinning operations. J. For. Res. 2010, 15, 358-364. [CrossRef]

60. STATISTICA. Data Analysis Software System; StatSoft Inc.: Tulsa, OK, USA, 2012.

61. Forestry Commission. The iron horse. For. Res.-Tech. Dev. Branch 2001, 8, 3.

62. Gallis, C. Comparative cost estimation for forwarding small-sized beech wood with horses and mini-skidder in northern Greece. For. Prod. J. 2004, 54, 84-90.

63. Stempski, W. Effects of wood layout on the load forming time with a forwarder. Nauka Przyr. Tech. 2012, 6, 2-11.

64. Väätäinen, K.; Ala-Fossi, A.; Nuutinen, Y.; Röser, D. The effect of single grip harvester's log bunching on forwarder efficiency. Balt. For. 2006, 12, 64-69.

65. Official Journal of the European Communities. Council Directive of 29 May 1990 on the Minimum Health and Safety Requirements for the Manual Handling of Loads Where There Is a Risk Particularly of Back Injury to Workers. In Proceedings of the Fourth Individual Directive within the Meaning of Article 16 (1) of Directive 89/ 391 /EEC), Brussels, Belgium, 29 May 1990.

66. Labuttis, J. Ergonomics as element of process and production optimization. Procedia Manuf. 2015, 3, 4168-4172. [CrossRef]

67. Leszczyński, K.; Rebizak, T. Ocena uciążliwości pracy wynikającej z ręcznego transportu drewna średniowymiarowego z wykorzystaniem różnych narzędzi pomocniczych (Evaluation of the Arduousness of Work Resulting from Manual Handling of Medium-Sized Timber with the Use of Various Auxiliary Tools). In Nowoczesne Technologie i Inżynieria w Zrównoważonym Użytkowaniu Lasu; Klamerus-Iwan, A., Ed.; Wydawnictwo Uniwersytetu Rolniczego w Krakowie: Kraków, Poland, 2020; pp. 27-40. 